\title{
Effect of three organic fertilizers treatments on sensory evaluations of baby spinach (Spinacia oleracea L.)
}

\author{
Parwada, $\mathbf{C}^{1,2}$., Chigiya, $\mathbf{V}^{1,3}$., Ngezimana, $\mathbf{W}^{1}$. \& Chipomho, $\mathbf{J}^{1}$. \\ ${ }^{1}$ Marondera University of Agricultural Sciences and Technology, Department of Horticulture, P. O. Box 35 Marondera, Zimbabwe \\ ${ }^{2}$ Faculty of Agricultural Sciences, Department of Horticulture, Women's University in Africa, P.O. Box 1175, Marondera, Zimbabwe \\ ${ }^{3}$ Seke Teachers College, Mangwende Road, 16120, Chitungwiza P.O. Box Sk 41, Seke, Zimbabwe \\ Author for correspondence: cparwada@gmail.com
}

\begin{abstract}
Summary: Sources of fertilizer are one of the major factors influencing baby spinach leaf texture, sweetness, bitterness and after-taste. However, the effects of fertilizer sources on baby spinach growth performance and consumer preferences are not known. A survey was carried out at the Seke Teachers' College (SKC) community, Zimbabwe to determine the consumer preferences on the baby spinach grown on the organic fertilizer (cattle, poultry and goat manures) as well as on control inorganic fertilizers ( $7 \% \mathrm{~N}, 14 \% \mathrm{P}, 7 \% \mathrm{~K})$. The study used 32 females and 30 males as panellists for sensory evaluations. Organoleptic tests were performed for the baby spinach leaves using a panel of 62 testers. An interval line scale (16 cm long) was used to measure the liking for sweetness, colour, bitterness and after-taste. A 9-point hedonic scale was used to decide the overall preferences. Organoleptic tests showed significant differences $(\mathrm{P}<0.05)$ in appearance and taste between the inorganic and organic fertilizers used. The baby spinach leaves grown on organic fertilizers was preferred more compared to that grown on inorganic fertilizer (control). Therefore, it is recommended to use organic fertilizers in baby spinach production in order to satisfy consumer preferences.
\end{abstract}

Parwada, C., Chigiya, V., Ngezimana, W., Chipomho, J. (2021): Effect of three organic fertilizers treatments on sensory evaluations of baby spinach (Spinacia oleracea L.). International Journal of Horticultural Science 27: 59-63. https://doi.org/10.31421/ijhs/27/2021/8670

Key words: foliar concentrations, preferences, residual chemicals, slow release, taste

\section{Introduction}

Spinacia oleracea L. (baby spinach) is a leafy vegetable which is rich in core nutrients and phytochemicals (Mehta \& Belemkar, 2014). The crop is relatively new and has proved increasingly popular in recent years due to its nutritional value (Hedges \& Lister, 2007). The S. oleracea is high in vitamin C, as well as other minor elements such as magnesium $(\mathrm{Mg})$, zinc (Zn), iron (Fe) and selenium (Se) (Parwada et al., 2020). The production practices, such as fertilization, deficit irrigation, and postharvest storage conditions and duration (Mudau et al., 2006), have an impact on the bioactive compounds as well as on the taste of leaf vegetables (Turkmen et al., 2005). Application of fertilizer has contributed to improvement in the baby spinach yield and nutrition (Wang et al., 2008).

The source of fertilizer has a major influence on the baby spinach leaf taste. Organic manure such as cattle, goat and poultry manure among others can be used in the production of the crop. In addition, inorganic fertilizers are also important sources of nutrients for the baby spinach. Nevertheless, the source of fertilizers impacts differently on the leaf quality of the vegetable. The leaf taste is one of the quality indicators of the baby spinach. The quantities and state of nutrient elements such as $\mathrm{N}, \mathrm{P}, \mathrm{K}, \mathrm{Ca}, \mathrm{Mg}$ contained in a fertilizer affects the leaf quality hence consumers taste preferences of the baby spinach (Wang et al., 2008).

The $\mathrm{N}$ is essential for crop growth and development where limiting levels of the available $\mathrm{N}$ result in stunted growth and leaf chlorosis in plants due to reduced chlorophyll pigmentation (Sainju et al., 2003). The $\mathrm{N}$ requirement for the baby spinach varies from 21 to $45 \mathrm{~kg} \mathrm{ha}^{-1}, 63$ to $138 \mathrm{~kg} \mathrm{ha}^{-1} \mathrm{P}$, and 22 to 45 $\mathrm{kg} \mathrm{ha}^{-1} \mathrm{~K}$ (Parwada et al., 2020). High levels of $\mathrm{N}\left(>45 \mathrm{~kg} \mathrm{ha}^{-1}\right.$ ) may increase vegetative growth in the $S$. oleracea causing light starvation in some parts of the plant leading to a modification in the chemical composition of such parts (Lee \& Kader, 2000). The $\mathrm{P}$ enhances quality of the vegetables in many ways, e.g the chemical composition, marketability and storability of the crop (King et al., 2008). Potassium has the strongest impact on baby spinach leaf quality parameters that determine consumer preference (Jifon \& Lester, 2009). The $\mathrm{K}$ is an essential major nutrient for crop growth and is required for vital physiological processes such as metabolism, growth, and stress adaptation (de la Rosa et al., 2001). Bunea et al. (2008), observed a significant correlation between the content of total flavonoids and some high-molecular-weight polyphenols and level of soil N, P \& K in traditional spinach.

The $S$. oleracea is characterised by a short picking window period from planting to harvesting; therefore, strategy intervention is important in order to enhance growth and nutritional quality. In the wake of modernised lifestyles and increasing demand for leafy vegetables, consumption of the fresh-cut spinach as salad has increased partly because of its high nutritional value and health benefits (Zikalala et al., 2016). To meet increased demand, fertilization becomes a common phenomenon. However, excessive application of inorganic fertilizers (quick-release) has often resulted in the accumulation of high quantities of nitrates in the plant tissue (Bunea et al., 2008). This reduces the leaf quality in vegetables. 
The organic fertilizers (slow-release) have become popular due to consumer concern on health and the environment issues, albeit, the defining features of the organic fertilizer remain vague. The organic fertilizers had proved to enhance soil health and productivity (Sharma \& Agarwal, 2014).

Currently, there is no information on the impact of the organic fertilizers on the quality of the baby spinach. Considering that the $S$. oleracea is relatively a new horticultural crop in Zimbabwe, many evaluations on the crop are required. The common evaluations include the toxicological tests, consumer and other physicochemical studies (Gamble et al., 2006). While physicochemical and toxicological studies indicate the composition of the vegetable and its safety to consumers, consumer evaluations show how well the new product will fare on the market. Information on the effect of mineral nutrition on growth and development, as well as on the leaf quality of baby spinach grown under chemical fertilizers is available (Nemadodzi et al., 2017; Zikalala et al., 2016). However, it is important to investigate optimal management practices, specifically organic fertilisation management and its effects on the organoleptic performance of baby spinach. Therefore, the objective of this study was to determine the effect of three organic fertilizers on the sensory quality of baby spinach.

\section{Materials and methods}

\section{Experimental site}

The study was carried out during the winter season of 2019 at Seke Teachers College (STC), Zimbabwe experimental fields, (18 $01^{\circ}$ ' 98' S and $31^{\circ} 06^{\prime} 79^{\prime \prime} \mathrm{E}$ ) situated about $26 \mathrm{~km}$ south of Harare the capital city of Zimbabwe. The area experiences a hot dry summer season from August to October, a hot wet summer season (rainy season) from October/November to March/April and a cold dry winter season (dry season) from May to July. The area has an average annual rainfall of $850 \mathrm{~mm}$ of which $650 \mathrm{~mm}$ is effective for crop production. Average maximum and minimum temperatures are 25.3 and $12.2{ }^{\circ} \mathrm{C}$ respectively. The area is predominantly underlain by granitic parent rock which has given rise to sandy soils.

\section{Experimental design}

The experiment was preapred in a completely randomized block design (CRBD) with three replicates in the growing of the baby spinach field. The treatments were poultry, goat and cattle manure. Inorganic fertilizer (Compound D- 7\% N, 14\% $\mathrm{P}, 7 \% \mathrm{~K})$ was included as a control. The plots were blocked according to the slope and measured $1.2 \times 1.0 \mathrm{~m}$ with 3 rows in each plot and a $50 \mathrm{~cm}$ space in-between plots. A planting density of 166667 plants ha ${ }^{-1}$ was used.

\section{Soil and organic manure analysis}

A total of six soil samples were taken from the experimental site. The sampling was done at a depth of $0-20 \mathrm{~cm}$ using a graduated soil auger in June 2019 before sowing of the baby spinach. The experimental site was under fallow for more than 10 years. The soil samples were taken per plot $\left(1.2 \mathrm{~m}^{2}\right)$ and then randomly mixed to make a composite sample for analyses. The goat, poultry and cattle manures were sourced from STC livestock farm section. The manure was cured by sun-drying for three weeks to homogenize the moisture content. The curing process mimicked the manure treatment practice by the local farmers in the study area. After the drying, one kg sample was randomly taken for analysis and the bulky stored for use.

\section{Determination of soil chemical properties}

The $\mathrm{C}, \mathrm{N}$, the Olsen extractable $\mathrm{P}$, exchangeable ammonium and nitrate in both the organic manures (poultry, goat and cattle) and soil were analysed as described by Parwada et al. (2020).

\section{Production of the baby spinach}

Spinach cultivar, dash seeds were sown in a nursery bed on 14 July, 2019. After 14 days from sowing, uniform plants were selected and transplanted into permanent beds, with $15 \mathrm{~cm}$ distances between plants. Soil moisture was maintained at field capacity by irrigation throughout the study period. The inorganic fertilizer $(7 \% \mathrm{~N}, 14 \% \mathrm{P}, 7 \% \mathrm{~K})$ was from the Zimbabwe fertilizer company and applied before sowing using the blanket recommended rate $\left(300 \mathrm{~kg} \mathrm{ha}^{-1}\right.$ i.e $\left.21 \mathrm{~kg} \mathrm{~N} \mathrm{ha}^{-1}\right)$ in the study area. The organic manure application rates were also applied before sowing according to the blanket $\mathrm{N}$ recommended in the area. Therefore the amount of organic manure applied was determined by the amount of extractable $\mathrm{NO}_{2}+\mathrm{NO}_{3}\left(\mathrm{mg} \mathrm{kg}^{-1}\right)$ in the manure. The goat manure was applied at $14.894 \mathrm{t} \mathrm{ha}^{-1}$, cattle manure at $17.789 \mathrm{t} \mathrm{ha}^{-1}$ and the poultry manure at $13.807 \mathrm{t} \mathrm{ha}^{-1}$ according to the amount of the $\mathrm{NO}_{2}+\mathrm{NO}_{3}\left(\mathrm{mg} \mathrm{kg}^{-1}\right)($ Table 1).

\section{Organoleptic test}

At 14 days after transplanting, the baby spinach leaves were manually harvested using sharp knife by detaching the leaves from the stem. The harvesting was done in the morning. The raw leaves from the different fertilizer plots were prepared in a laboratory using the same procedure. The leaves were put in coded identical dishes. This was to minimize bias judgment of the panellists. The dishes were coded as follows: A for goat manure; B for inorganic fertilizer $(7 \% \mathrm{~N}, 14 \% \mathrm{P}, 7 \% \mathrm{~K}), \mathrm{C}$ for poultry manure and $\mathrm{D}$ for cattle manure. A total of 62 participants aging 18-45 years old were randomly chosen from the Seke Teachers College Community including both the staff and students. In order to determine the liking for sweetness, colour, bitterness and after-taste a $16 \mathrm{~cm}$ interval line scale was used. The panellists consisted of 32 females and 30 males. All the panellists (62) were made to taste each dish in the science laboratory at the STC Chitungwiza, Zimbabwe. A 10 minutes break with water to clear participants' pallet was included in between the tastings. Four tastings were done per respondent and then scored for liking on sweetness, colour, after-taste and bitterness. The panellists were asked to have an overall liking score for each dish using a 9- point hedonic scale (Table 2).

\section{Data analysis}

The observations were independent of each other; the score data were log-transformed to conform to a normal distribution and homoscedasticity. Frequency response graph and tables were used to present the data. Then the transformed data on panellists' preference was used in the analysis of variance (ANOVA) to compare the effects of sources of fertilizer on the sensory evaluation of the baby spinach. 
Table 1. The initial chemical properties of the soil at the at Seke Teachers College (STC), experimental field and organic manures used in the study

\begin{tabular}{lllll}
\hline & & \multicolumn{3}{l}{ Source of organic manure } \\
\hline Parameter & Soil & Goat & Cattle & Poultry \\
\hline $\mathrm{pH}\left(\mathrm{H}_{2} \mathrm{O}\right)$ & $4.5 \pm 0.1$ & $6.8 \pm 0.5$ & $7.15 \pm 0.3$ & $6.6 \pm 0.3$ \\
$\mathrm{EC}\left(\mathrm{dSm}^{-1}\right)$ & $3.1 \pm 0.02$ & $5.6 \pm 0.2$ & $5.85 \pm 0.1$ & $5.7 \pm 2.1$ \\
$\mathrm{CEC}\left(\mathrm{cmol}_{(+)} \mathrm{kg}^{-1}\right)$ & $71.0 \pm 0.1$ & $312.0 \pm 0.6$ & $216.2 \pm 0.7$ & $329.0 \pm 1.3$ \\
Total C $(\%)$ & $0.8 \pm 0.03$ & $22.0 \pm 0.7$ & $29.7 \pm 0.2$ & $20.1 \pm 1.4$ \\
Total N $(\%)$ & $0.9 \pm 0.04$ & $5.18 \pm 0.1$ & $3.10 \pm 0.1$ & $6.3 \pm 1.1$ \\
$\mathrm{C}: \mathrm{N} \mathrm{ratio}$ & $0.5 \pm 0.01$ & $4.2 \pm 1.2$ & $9.6 \pm 0.5$ & $3.2 \pm 0.8$ \\
Olsen extractable $\mathrm{P}_{\left(\mathrm{mg} \mathrm{kg}^{-1}\right)}$ & $401.0 \pm 2.11$ & $1300.0 \pm 5.3$ & $1210.6 \pm 6.5$ & $1320 \pm 4.1$ \\
$\mathrm{Extractable} \mathrm{NO} / \mathrm{NO}_{3}\left(\mathrm{mg} \mathrm{kg}^{-1}\right)$ & $33.2 \pm 1.03$ & $1410.0 \pm 7.4$ & $1180.5 \pm 6.7$ & $1521 \pm 5.1$ \\
$\mathrm{Extractable} \mathrm{NH}\left(\mathrm{mg} \mathrm{kg}^{-1}\right)$ & $111.4 \pm 0.9$ & $421.1 \pm 3.7$ & $391.6 \pm 1.6$ & $410.2 \pm 2.1$ \\
$\mathrm{Ca}\left(\mathrm{mg} \mathrm{kg}^{-1}\right)$ & $0.2 \pm 0.02$ & $24.2 \pm 3.2$ & $25.3 \pm 2.2$ & $30.1 \pm 3.1$ \\
$\mathrm{~K}\left(\mathrm{mg} \mathrm{kg}^{-1}\right)$ & $7.3 \pm 0.8$ & $3.1 \pm 0.6$ & $2.8 \pm 0.4$ & $3.5 \pm 0.8$ \\
$\mathrm{Mg}\left(\mathrm{mg} \mathrm{kg}^{-1}\right)$ & $30.6 \pm 1.4$ & $14.7 \pm 2.2$ & $12.2 \pm 1.5$ & $13.1 \pm 0.7$ \\
$\mathrm{Na}\left(\mathrm{mg} \mathrm{kg}^{-1}\right)$ & $0.54 \pm 0.06$ & $1.4 \pm 0.3$ & $1.7 \pm 0.1$ & $1.1 \pm 0.6$ \\
$\mathrm{Cu}\left(\mathrm{mg} \mathrm{kg}^{-1}\right)$ & $241.2 \pm 40.1$ & $344.1 \pm 36.2$ & $342.2 \pm 46.5$ & $333.1 \pm 36.2$ \\
$\mathrm{Zn}\left(\mathrm{mg} \mathrm{kg}^{-1}\right)$ & $100.5 \pm 8.7$ & $566.3 \pm 11.5$ & $537.3 \pm 0.4$ & $589.2 \pm 0.6$ \\
\hline
\end{tabular}

1) EC, electrical conductivity; CEC, cation exchange capacity

2) Data are means \pm standard error of the means for three replicates

\section{Results}

The soil and organic manures were characterised as shown in Table 1. Generally, the soil was lowest in the measured parameters as compared to the goat, poultry and cattle manure (Table 2). The poultry manure had the lowest $\mathrm{C} / \mathrm{N}$ ratio (3.2) and highest extractable $\mathrm{NO}_{2}+\mathrm{NO}_{3}\left(\mathrm{mg} \mathrm{kg}^{-1}\right)\left(1521 \mathrm{mg} \mathrm{kg}^{-1}\right)$ among the used organic manure sources (Table 2).

Table 2. Hedonic scale showing the overall degree of liking of vegetable

\begin{tabular}{ll}
9 & Like extremely \\
8 & Like very much \\
7 & Like moderately \\
6 & Like slightly \\
5 & Neither like nor dislike \\
4 & Dislike slightly \\
3 & Dislike moderately \\
2 & Dislike very much \\
1 & Dislike extremely \\
\hline
\end{tabular}

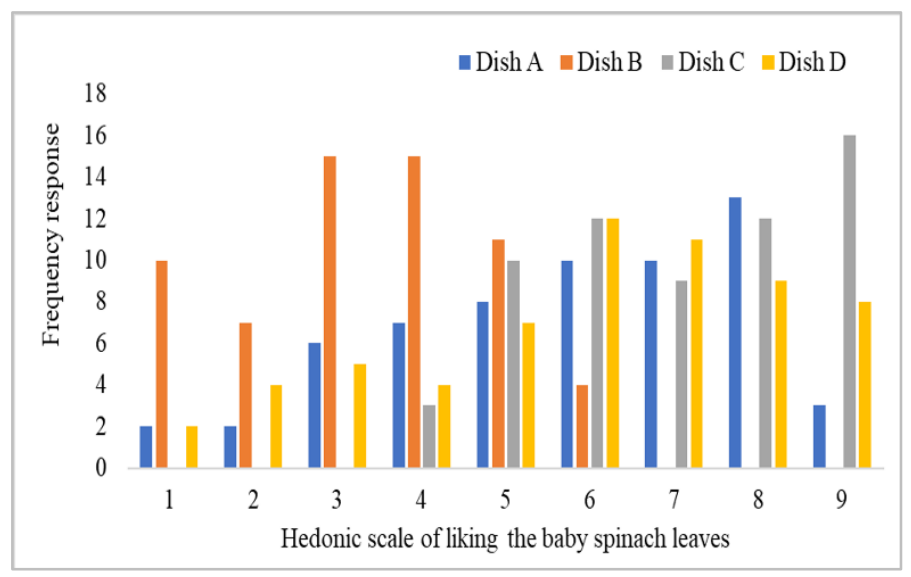

Figure 1. Overall sensory rating on the baby spinach leaves grown under different fertilizer sources

Dish $\mathrm{A}=$ goat manure, Dish $\mathrm{B}=$ Inorganic $(7 \% \mathrm{~N}, 14 \% \mathrm{P}, 7 \% \mathrm{~K})$, Dish $\mathrm{C}=$ Poultry manure and Dish $\mathrm{D}=$ cattle manure
The panellists' overall sensory rating on the baby spinach leaves grown from the different organic sources was evaluated as shown in Figure 1. On the overall sensory rating, about 58\% and $64 \%$ of the panellists indicated like moderately, like very much and like extremely for the leaf grown under goat and cattle manure respectively (Figure 1). Inorganic fertilizer had the least $(6 \%)$ while the poultry manure had the highest $(79 \%)$ of the panellists who indicated to like moderately, like very much and like extremely the baby spinach leaves (Figure 1). The baby spinach leaves from A (goat manure), C (poultry manure) and D (cattle manure) were generally skewed towards the higher grades of liking by the testers, i.e. $6+$ on the hedonic scale (Figure 1).

The level of liking of the baby spinach leaves was evaluated from the panelists (Table 3). Baby spinach leaves from B (inorganic fertilizer) was inclined towards lower grades, i.e. 4 and below. The summary statistics on liking indicated that baby spinach leaf $\mathrm{B}$ under inorganic fertilizer had the lowest mean rating while leaf $\mathrm{C}$ from poultry manure was rated highest (Table 3). The variation in the ratings was highest in leaf $\mathrm{B}$ implying that the tasters were quite divergent in their rating of baby spinach leaf produced under inorganic fertilizer. The baby spinach leaf $\mathrm{C}$ had the greatest mean rating, indicating that the tasters were very consistent as evidenced by the small standard deviation and the maximum and minimum ratings from 4 to 9 (Table 3).

Table 3. Summary statistics for the leaf liking score ratings by the 62 panellists

\begin{tabular}{lllccc}
\hline Leaf & Observed & Mean & \pm Std. & Minimum & Maximum \\
\hline A & 62 & 6.48 & 1.71 & 2 & 9 \\
B & 62 & 4.27 & 2.87 & 1 & 8 \\
C & 62 & 7.69 & 1.19 & 4 & 9 \\
D & 62 & 6.03 & 1.57 & 2 & 9 \\
\hline
\end{tabular}

Leaf $\mathrm{A}=$ goat manure, Leaf $\mathrm{B}=$ Inorganic $(7 \% \mathrm{~N}, 14 \% \mathrm{P}, 7 \% \mathrm{~K})$, Leaf $\mathrm{C}=$ Poultry manure and Leaf $\mathrm{D}=$ cattle manure

There were significant $(\mathrm{P}<0.05)$ differences in the sweetness, bitterness, colour and after-taste of the baby spinach 
leaves between the organic and inorganic fertilizers. However, no significant $(\mathrm{P}<0.05)$ differences in the sensory parameters were observed among the used organic manure (Table 4). Baby spinach grown on inorganic fertilizer had significantly the lowest sweetness (0.42), most bitterness (0.63), most unattractive colour (0.39) and highest effects on the after-taste (0.74) compared to the organic manures (Table 4).

Table 4. The 9-point hedonic scale rating on effects of source of fertilizer on the sensory parameters of baby spinach

\begin{tabular}{lcccc}
\hline \multirow{2}{*}{$\begin{array}{l}\text { Source of } \\
\text { fertilizer }\end{array}$} & Sweetness & Bitterness & Colour & $\begin{array}{c}\text { After- } \\
\text { taste }\end{array}$ \\
\cline { 2 - 5 } & 0.70 & 0.42 & 0.50 & 0.25 \\
Goat & 0.42 & 0.63 & 0.39 & 0.74 \\
Inorganic & 0.76 & 0.41 & 0.56 & 0.29 \\
Poultry & 0.69 & 0.44 & 0.51 & 0.28 \\
Cattle & $\mathbf{0 . 0 7}$ & $\mathbf{0 . 0 4}$ & $\mathbf{0 . 0 6}$ & $\mathbf{0 . 0 7}$ \\
\hline LSD & & & &
\end{tabular}

LSD was prepared at $\mathrm{P}=0.05$

\section{Discussion}

Generally, the baby spinach on organic manure was preferred more compared to that from inorganic fertilizer. In this study, applied $\mathrm{N}\left(21 \mathrm{~kg} \mathrm{ha}^{-1}\right)$ and $\mathrm{P}, \mathrm{K}$ was approximately the same from both the organic manures and inorganic fertilizer (inorganic fertilizer). This suggests that the observed sensory qualities of the baby spinach were influenced by the source of the fertilizer rather than the nitrogen quantities (Sharma \& Agarwal, 2014). The sensory qualities of the baby spinach were significantly $(\mathrm{P}<0.05)$ enhanced by the applied organic manures (goat, poultry and cattle) The results are similar to $\mathrm{Xu}$ et al. (2005) who observed higher total yield and better sensory qualities in spinach grown on organic than inorganic fertilizers. The concentration of nitrates in the foliar was directly proportional to the rate of nutrient release by a fertilizer (Chat et al., 2005). Worthington (2018) noted that the quick-release (inorganic) fertilizers had higher concentrations of leaf nitrates in vegetables than the slow release (organic) fertilizers. In this study, the organic manures resulted to lower rates of toxic compounds accumulation such as nitrates hence the better sensory qualities. This suggested that organic manures enhanced the sensory qualities of the baby spinach.

The skewness of the grades towards higher values on the hedonic scale i.e. $6+$ for the baby spinach under goat, poultry and cattle manures indicated the panellists preferred spinach grown on the organic fertilizers. The sensory evaluations on the baby spinach quality grown on inorganic fertilizer were inclined towards lower grades i.e. 4- indicating less preference. Similar results were found by Chat et al. (2005) who noted a high leaf growth and physiochemical leaf quality on spinach under poultry, cattle and sheep manures. The findings also concur to Canali et al. (2008) who reported that $\mathrm{N}$ from farmyard manure resulted in higher leaf yield and quality of spinach.

The observed variations in the frequency responses on rating among the organic manures could be due to specific differences in preferences by the tasters. This research did not ascertain the tasting preferences between the males and females but generally, females had sweeter tongues compared to their male counterparts and this could explain the variations observed on the response frequencies (Sharma \& Agarwal, 2014). The baby spinach grown under organic manures was sweeter than on inorganic fertilizer (Dish B). The baby spinach from poultry manure was liked most compared to goat and cattle manure. The results were similar to Nemadodzi et al. (2017) who found no significant $(\mathrm{P}>0.05)$ differences on the organoleptic tests for preference taste and appearance of red lettuce grown under different types of fertilizers.

\section{Conclusion and recommendations}

The source of fertilizer rather than quantities of nutrient elements influenced the sensory qualities of the baby spinach. The organic fertilizers enhanced the sweetness, impacted an attractive colour in the baby spinach leaves and reduced the bitterness and after-taste in the baby spinach leaves. The panellists despised the inorganic fertilizer (inorganic fertilizer). Therefore, it is recommended to use organic fertilizer sources when producing the baby spinach in order to enhance its sensory qualities. However, further studies investigating the intrinsic nutritional qualities of the baby spinach leaves in response to the sources of organic manure are required.

\section{Acknowledgements}

This work did not receive any funding, but was done as part of employment at the Marondera University of Agricultural Sciences and Technology, Zimbabwe and the Women's University in Africa, Zimbabwe. The authors gratefully acknowledge the Seke Teachers College, Department of Agricultural Education for the resources to carry this study in their laboratories.

\section{References}

Bunea, A., Mirjana, A., Carmen, S., Bobis, O., Neacsu, M., Verhé, R., van Camp, J. (2008): Total and individual carotenoids and phenolic acids content in fresh, refrigerated and processed spinach (Spinacia oleracea L.). Food Chem. 108: 649-656. https://doi.org/10.1016/j.foodchem.2007.11.056

Canali, S., Montemurro, F., Tittarelli, F., Masetti, O. (2008): Effect of nitrogen fertilization reduction on yield, quality and $\mathrm{N}$ utilisation of processing spinach. J. Food Agric. Envir. 6: 242-247.

Chat, T.H., Dung, N.T., Binh, D.V., Preston, T.R. (2005): Effect on yield and composition of water spinach (Ipomoea aquatica), and on soil fertility, of fertilization with worm compost or urea. Lives. Res. Rural Dev. 17: 20-25.

de la Rosa, T.M., Julkunen-Tiitto, R., Lehto, T., Aphalol, P.J. (2001): Secondary metabolites and nutrient concentrations in silver birch seedlings under five levels of daily UV-B exposure and two relative nutrient addition rates. New Phytol. 150: 121-131. https://doi.org/10.1046/j.1469-8137.2001. 00079.x

Gamble, J., Jaeger, S., Harker, F.R. (2006): Preferences in pear appearance and response to novelty among Australian and New Zealand consumers. Postharv. Biol. Technol. 41: 38-47. https://doi.org/10.1016/j.postharvbio.2006.01.019

Hedges, L.J., Lister, C.E. (2007): Nutritional attributes of spinach, silver beet and eggplant. New Zealand Institute for Crop and Food Research Limited. 
Jifon, J.L., Lester, G.E. (2009): Foliar potassium fertilisation improves fruit quality of field-grown muskmelon on calcareous soils in South Texas. J. Sci. Food and Agric. 89: 2452-2460. https://doi.org/10.1002/jsfa.3745

King, S., Davis, A., Perkins-Velazie, P., Helms, A., Stein, L. (2008): Effects of mineral nutrition on carotenoid content in spinach. HortSci. 43: 1246.

Lee, S.K., Kader, A.A. (2000): Pre-harvest and postharvest factors influencing vitamin $\mathrm{C}$ content of horticultural crops. Postharv. Biol. Techn. 20: 207-220. https://doi.org/10.1016/ S0925-5214(00)00133-2

Mehta, D., Belemkar, S. (2014): Pharmacological activity of Spinacia oleracea L.: A complete overview. Asian J. Pharm. Res. and Devel. 2: 83-93.

Mudau, F.N., Soundy, P., Du Toit, E.S., Oliver, J. (2006): Variation in polyphenolic content of Athrixia phylicoides (L.) (Bush tea) leaves with season and nitrogen application. S.A. J. Bot. 72: 398-402. https://doi.org/10.1016/j.sajb.2005.10.007

Nemadodzi, L.E., Araya, H., Nkomo, M., Ngezimana, W., Mudau, N.F. (2017): Nitrogen, Phosphorus, and Potassium effects on the physiology and biomass yield of baby spinach (Spinacia oleracea L.). J. Plant Nutri. 40: 2033-2044. https://doi.org/10.1080/01904167.2017.1346121

Parwada, C., Chigiya, V., Ngezimana, W., Chipomho, J. (2020): Growth and performance of baby spinach (Spinacia oleracea L.) grown under different organic fertilizers. Inter. J. Agro. Article ID 8843906. https://doi.org/10.1155/2020/ 8843906.

Sainju, U.M., Dris, R., Singh, B. (2003): Mineral nutrition of tomato. J. Food Agric. Environ. 1:176-183.
Schoenau, J.J., O’Halloran, I.P. (2006): Sodium bicarbonateextractable phosphorus. In: M.R. Carter et al, editors. Soil Sampling and Methods of Analysis $2^{\text {nd }}$ edition. Canada: Canad. Soc. Soil Sci. 42: 89-95.

Sharma. J., Agarwal, S. (2014): Impact of organic fertilizers on growth yield and quality of spinach. Indian J. Plant Sci. 3: 37-43.

Turkmen, N., Sari, F., Velioglu, Y.S. (2005): The effect of cooking methods on total phenolics and antioxidant activity of selected green vegetables. Food Chem. 93: 713-718. https://doi.org/10.1016/j.foodchem.2004.12.038

Wang, Z.H., Li, S., Malhi, S. (2008): Effects of fertilisation and other agronomic measures on nutritional quality of crops. J. Sci. Food and Agric. 88: 7-23. https://doi.org/10.1002/ jsfa.3084

Worthington, V. (1998): Effect of agricultural methods on nutritional quality: a comparison of organic with conventional crops. Alter. Ther. Health Med. 4: 58-69.

Xu, H.X., Weng, X.Y., Yang, Y. (2005): Effect of phosphorus deficiency on the photosynthetic characteristics of rice plants. Rus. J. Plan Phys. 54: 741-8. https://doi.org/10.1134/ S1021443707060040

Zikalala, B.O., Nkomo, M., Araya, H., Ngezimana, W., Mudau, F.N. (2016): Nutritional quality of baby spinach (Spinacia oleracea L.) as affected by nitrogen, phosphorus and potassium fertilisation. S.A. J. Plant and Soil. 24. 1-8. https://doi.org/10.1080/02571862.2016.1225231 